\title{
SCHIST BELT OF TIPASJÄRVI IN THE PARISH OF SOTKAMO, FINLAND
}

\author{
H. VARTIAINEN \\ Rautaruukki Co., Rovaniemi, Finland
}

\begin{abstract}
The basement complex of eastern Finland near the schist belt of Tipasjärvi, the rocks of the schist area (arenites, argillites, amphibolites and ultrabasic rocks), the late kinematic granites and the dikes of the Tipasjärvi district are described. The tectonics of the schist belt is described and the position of the schist area in the evolution of the bedrock in eastern Finland is discussed. It is suggested that the schist belt of Tipasjärvi might be a part of the formations deposited on the basement but which are older than the Karelian (Sariolan, Jatulian, Kalevian) formations. Other schist areas of the same age are, perhaps, those of Kuhmo-Suomussalmi and Ilomantsi.
\end{abstract}

\section{Introduction}

The auther carried out geological mapping in the Tipasjärvi district in the summer of 1962. The work was connected with the prospecting operations of the Suomen Malmi Co. On the basis of this field work the author wrote thesis for his degree of M.A. at the University of Oulu (Vartiainen, 1965) under the direction of Professor Juhani Seitsaari.

The present paper deals with the schist area of Tipasjärvi, which has not previously been described in detail in literature. Lake Tipasjärvi is situated in the parish of Sotkamo in eastern Finland, about $90 \mathrm{~km}$ ESE from the town of $\mathrm{Ka}$ jaani (Fig. 1). The schist belt of Tipasjärvi is about $12 \mathrm{~km}$ long and $4 \mathrm{~km}$ wide (Fig. 2).

South of the schist area is found the basement complex of eastern Finland, on which the sedimentary rocks of the schist belt are deposited. The southern and at the same time the lower part of the schist belt consist of arenaceous sedimentary rocks. These are followed by the zone of metamorphosed basic and ultrabasic rocks of magmatic origin. A wide mica schist bed composes the upper part of the schist belt. Thin black schist beds occur here and there in the schist area. South-east and north of the schist area younger, late kinematic granites occur. Metadiabases and aplites penetrate the schists.

The tectonics of the schist area is also presented. The position of the schist area in the evolution of the bedrock in eastern Finland is discussed.

\section{Basement and basal schist}

B a s e ment. The basement of the Tipasjärvi district belongs to the basement complex in eastern Finland. This complex is fairly heterogenous containing rocks from ultramafic to pot- 


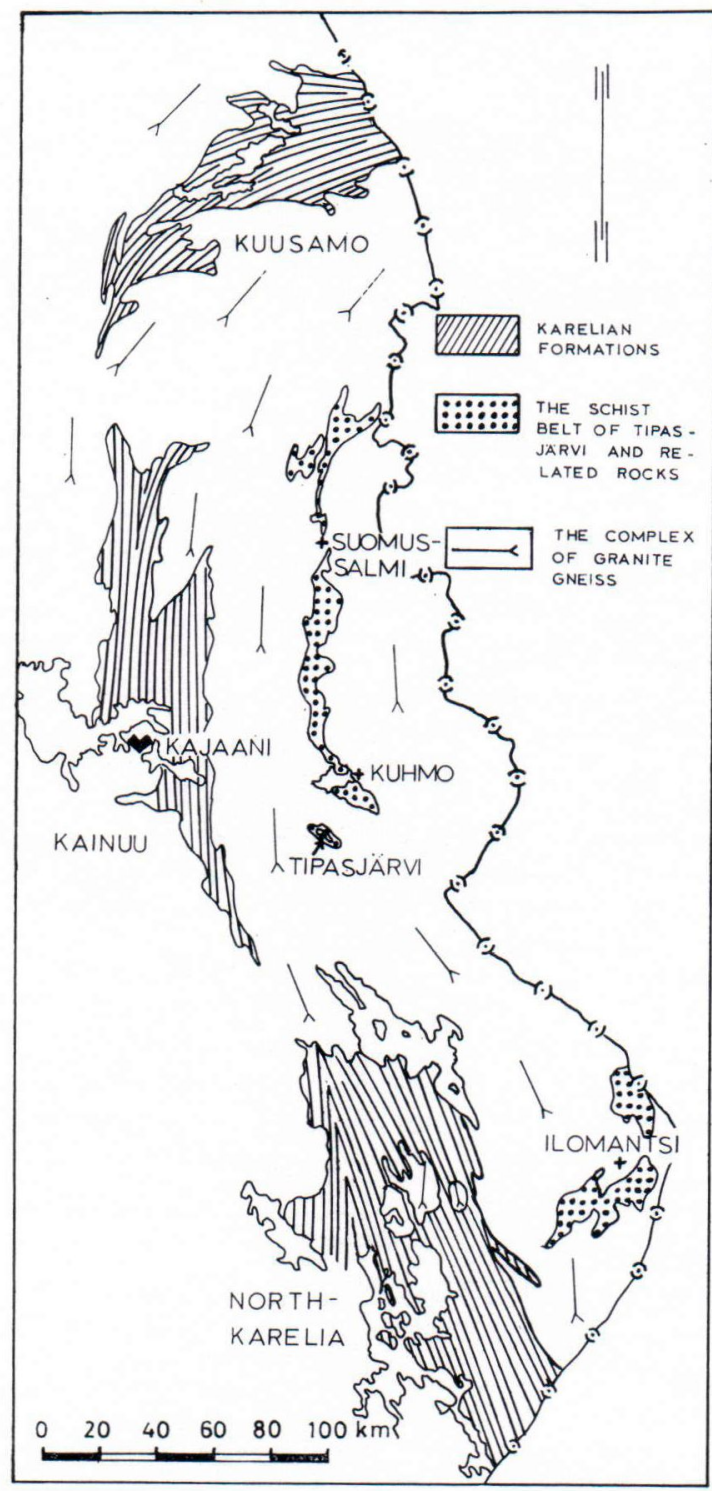

Fig. 1. Schist belts in eastern Finland.

ash granites (Simonen, 1960, Eskola, 1963). The composition of the basement in Tipasjärvi is quartz dioritic (Table 1). Its strike conforms with the southern edge of the schist belt. Microscopically the quartz dioritic granite gneiss is cataclastic.

$\mathrm{B}$ a s a $1 \mathrm{~s} \mathrm{ch}$ is t. Between the $\mathrm{SW}$ boundary of the schist belt and the basement a rock variety
TABLE 1

Modal compositions of basement and late kinematic granites.

\begin{tabular}{l|r|r|r|r|r}
\hline & \multicolumn{1}{|c|}{1} & \multicolumn{1}{c|}{2} & \multicolumn{1}{c|}{3} & \multicolumn{1}{c|}{4} & \multicolumn{1}{c}{5} \\
\hline & & & & \\
Plagioclase ..... & 36.0 & 47.2 & 36.5 & 49.3 & 48.0 \\
Quartz ....... & 46.8 & 35.6 & 36.0 & 26.1 & 35.1 \\
Potash feldspar .. & 1.6 & 7.9 & 23.8 & 16.7 & 14.5 \\
Biotite ........ & 4.8 & 4.6 & - & 4.7 & 1.3 \\
Muscovite ...... & - & 3.4 & 3.5 & 2.3 & 0.1 \\
Epidote ....... & 3.6 & - & - & - & - \\
Accessories ..... & 0.2 & 1.3 & 0.2 & 0.9 & 1.0 \\
\hline & 100.0 & 100.0 & 100.0 & 100.0 & 100.0 \\
\hline
\end{tabular}

1. Basement, quartzdioritic, striped, gray

2. Basement, quartzdioritic, massive, reddish

3. Latekinematic granite, cataclastic

4. Latekinematic granite, massive, red

5. Latekinematic granite, massive, gray

occurs which is called here basal schist. It is a medium-grained and schistose rock grading into the basement and arenites. The basal schist probably originated tectonically when the schist belt and the basement have sheared against each other.

\section{Arenites}

Meta-arkose. Only two outcrops of meta-arkose are found, both of which are situated about $100 \mathrm{~m}$ from the basement. Thus, unfortunately, the relation between the meta-arkose and the basement cannot be established. The matrix of the meta-arkose is macroscopically brownish gray. It consists of quartz, plagioclase, micas, chlorite, epidote and opacite. Whitish quartz and plagioclase pebbles is on an average $50 \%$ of the volume of the rock.

M i c a - f e ld s par-quart $z-s c h i s t$. The meta-arkose grades gradually upwards to the chlorite-felspar-quartz-schist as first the palgioclase and then also the quartz pebbles disappear. Thus, the clastic structure becomes granoblastic. The chlorite-feldspar-quartz-schist is a medium- or fine-grained and strongly schistose rock. 

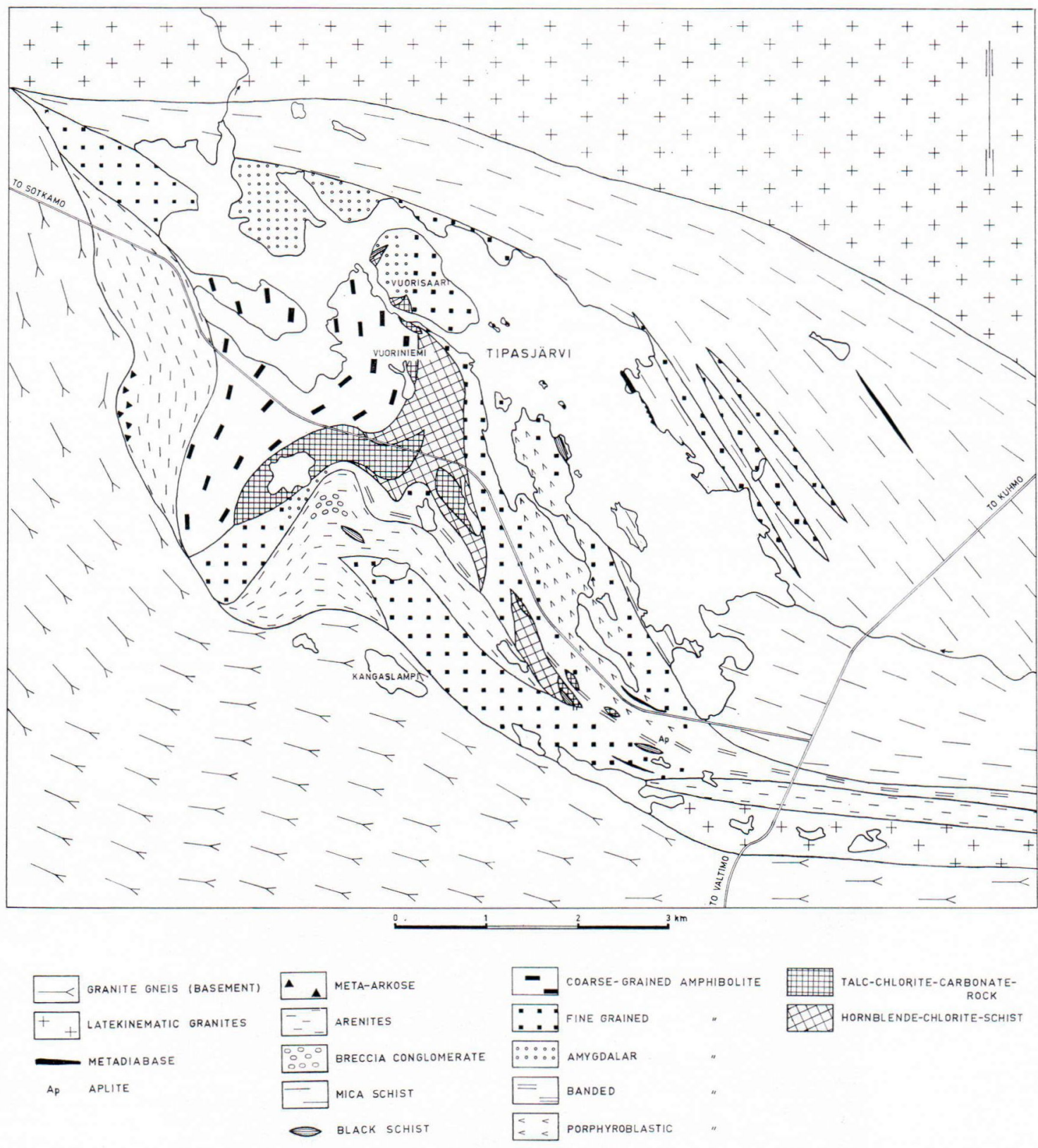

Fig. 2. Geological map of Tipasjärvi district

Mic a-quartz-s chist. There are two mica-quartz-schist beds on the southern side of the schist belt (Fig. 2). Originally these might have been of the same stratum that later tectonic events broke up. The mica-quartz-schist is a heterogenous rock. White layers, which are rich in quartz, plagioclase and muscovite, intercalate with gray layers rich in biotite. The width of the layers ranges from some centimetres to tens of metres. The contacts of the layers are either 
TABLE 2

Modal compositions of amphibolite varieties.

\begin{tabular}{l|r|r|r|r}
\hline & \multicolumn{1}{|c|}{1} & \multicolumn{1}{c|}{2} & \multicolumn{1}{c}{3} & \multicolumn{1}{c}{4} \\
\hline Hornblende .... & 72.8 & 81.2 & 81.3 & 65.3 \\
Quartz ....... & 7.6 & 13.5 & 8.0 & 15.2 \\
Plagioclase .... & 1.9 & 0.8 & 8.3 & 13.7 \\
Carbonate ..... & 13.2 & 2.2 & - & - \\
Chlorite ....... & 3.9 & - & - & - \\
Biotite ....... & - & - & - & 3.8 \\
Apatite ....... &.- & 0.1 & - & 0.7 \\
Ore ........ & 0.6 & 2.2 & 2.4 & 1.3 \\
\hline & 100.0 & 100.0 & 100.0 & 100.0 \\
\hline
\end{tabular}

1. Coarse-grained amphibolite

2. Fine-grained amphibolite

3. Amygdalar amphibolite

4. Amphibolite containing hornblende porphyroblasts

sharp or diffuse. The primary sedimentary features have almost wholly disappeared. One outcrop is found where graded beding is preserved (Fig. 3). This shows bottom direction to the basement. Sometimes blastoclastic structures are also seen. The recrystallisation and the schistosity of the mica-quartz-schist is intensive.

B r e c c i a - c onglo merat e. A few conglomeratic outcrops occur in the mica-quartzschist. These have clear features of interform- ational conglomerate but, on the other hand, breccia structures are also apparent. The brecciaconglomerate of Tipasjärvi has been descriped previously (Vartiainen, 1966).

\section{Argillites}

Mica-s chist. The nothern part of the schist belt consists of a broad mica schist bed (Fig. 2). The contact with amphibolites is sharp but the border area against late kinematic granite is covered by soil. The mica schist is composed of irregular lighter and darker layers. Their differences are due to the quantity of femic minerals and grain size; the more femic the minerals and the smaller the grain size, the darker is the layer in question. Strong metamorphism has destroyed the original sedimentary structures of the mica schist. Because of the unstable character of the rock, the mineral composition varies. Chief minerals are biotite, quartz, muscovite and chlorite. In places (light layers) the amount of the plagioclase is also fairly high.

$\mathrm{B} l \mathrm{ack} \mathrm{sch}$ ist. The black schist is also described in this connection, since its material is not merely sapropelic but also argillaceous. It

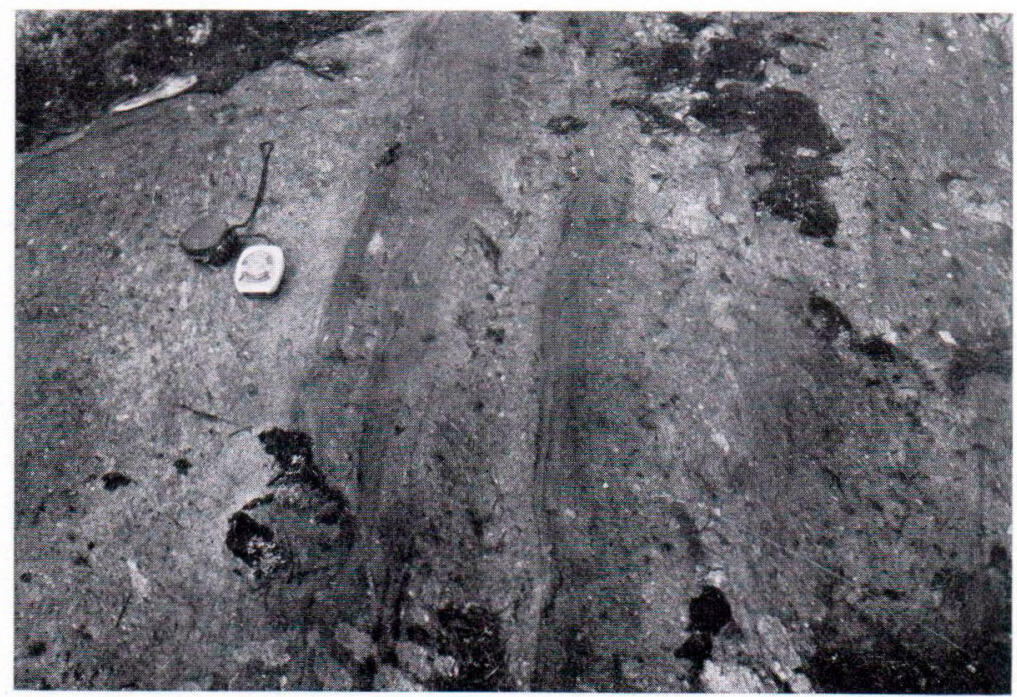

Fig. 3. Graded bedding in the mica-quartzite-schist. 
occurs in the schist area as thin beds (Fig. 2) and is composed of thin black and light layers (breadth $1.0-5.0 \mathrm{~mm}$ ). The black layers are rich in graphite. Quartz, plagioclase and chlorite are the chief minerals of the light layers.

\section{Amphibolites}

Amphibolites occur as a wide zone in the central parts of the schist area (Fig. 2). The amphibolites can be divided into five types:

- coarse-grained amphibolite

- fine-grained amphibolite

- amygdalar amphibolite

- banded amphibolite

- amphibolite containing hornblende porphyroblasts

The modal compositions of the different amphibolites are listed in Table 2. These reveal that all the amphibolites are fairly basic. Table 3 presents the optical properties of hornblende and the anorthite content of plagioclase in the various amphibolites.

The coarse-grained a mphibolite occurs in the western part of the schist belt (Fig. $2)$. It is a monotonous and wholly metamorphosed rock. All the primary features have disappeared. The grain size of hornblende is on an average $0.5-2.0 \mathrm{~cm}$. Other minerals form a finegrained matrix between the hornblende grains.

TABLE 3

Optical properties of hornblende and anorthite content of plagioclase in the varieties of amphibolite.

\begin{tabular}{l|c|c|c|c|c}
\hline & $2 \mathrm{~V}_{\mathbf{x} \pm 2^{\circ}}$ & $\mathrm{c} \wedge \mathrm{z}$ & $\mathrm{z}-\mathrm{x}$ & $\begin{array}{c}\text { colour } \\
\text { in z-direc. }\end{array}$ & $\begin{array}{c}\text { An- } \% \\
\text { of plag. }\end{array}$ \\
\hline $1 \ldots$. & $76^{\circ}$ & $15^{\circ}$ & 0.022 & green & $33-46 \%$ \\
$2 \ldots$. & $74^{\circ}$ & $17^{\circ}$ & 0.022 & green & $30-40 \%$ \\
$3 \ldots$ & $76^{\circ}$ & $17^{\circ}$ & 0.022 & green & $28-35 \%$ \\
$4 \ldots$. & $77^{\circ}$ & $18^{\circ}$ & 0.023 & green & $23-40 \%$ \\
$5 \ldots$ & $73^{\circ}$ & $17^{\circ}$ & 0.021 & green & $20-33 \%$ \\
\hline
\end{tabular}

1. Coarse-grained amphibolite

2. Fine-grained amphibolite

3. Amygdalar amphibolite

4. Banded amphibolite

5. Hornblende porphyroblastic amphibolite

$3 \quad 5814-70$
Other types are fine-grained. Their medium grain size is $1.0-1.5 \mathrm{~mm}$. Generally, they are distinctly schistose and strongly recrystallised. The fine-grained amphibolites show sharp contacts against the mica schist and they form layerlike intrusions into the mica-quartz-schist. Amygdalar features demonstrate the extrusive nature of the rocks.

The fine-grained a mphibolite is a fairly homogenous rock without any distinct structural features.

The amygdalar amphibolite contains white amygdales filled with quartz and plagioclase.

The banded a mpholite consists of dark and light bands (breadth $5-30 \mathrm{~cm}$ ). The mineral composition of the bands is almost constant, but the grain size varies. In the dark bands the grain size of the femic minerals is greater than that of the light minerals.

The amphibolite containing hornblende porphyroblasts has received its name from its peculiar porphyroblastic structure. It is composed of hornblende porphyroblasts $0.5-1.5 \mathrm{~cm}$ in size, which have been oriented by schistosity. Between the porphyroblasts there is a fine-grained matrix containing about equal amounts of femic and salic minerals.

\section{Ultrabasic rocks}

One great ultrabasic deposit and several small lenses occur in the schist area (Fig. 2). Two kinds of ultrabasic rocks can be distinguised. These are named according to the chief minerals:

- talc-chlorite-carbonate-rock

- hornblende-chlorite-schist

The talc-chlorite-carbonate$\mathrm{rock}$ is massive and fine-grained. Its colour varies according to the diverse amounts of the chief minerals. Light green types are rich in talc and darker green varieties have more carbonate 
and chlorite. The places rich in talc are soapstonelike. Talc and chlorite form in the typical talcchlorite-carbonate-rock a small-meshed, net-like structure in which carbonate is discerned as porphyroblastic grains.

The hornblende-chlorite-schis t is a medium green and fine-grained rock. It is strongly schistose and partly foliated, breaking easily into thin flakes. As a whole the schist is macroscopically fairly homogenous. It is reaveled under the microscope that the hornblende-chlorite-schist contains thin shear planes covered by hornblende and chlorite and coarse-grained layerlike units. In the shear planes the amounts of hornblende and chlorite are equal but in the coarse layers there is more hornblende than chlorite.

\section{Late kinematic granites}

According to location, structure and mineralogy there are two kinds of late kinematic granites in the Tipasjärvi district. A massive granite is situated north of the schist belt and a cataclastic granite type occurs to the south-east of the schist area (Fig. 2).

The massive granite is mediumgrained and massive, grey or red in colour and with a granular texture. Its mineralogical composition is given in Table 1.

The cataclastic granite is pressed as a thin wedge between the schist belt and the basement (Fig. 2). The contacts against the bordering rocks are covered by soil in the same way as the contacts of the massive granite. However, a few boulders of the cataclastic granite have been found which contain fragments from the schist belt. This indicates that the granite is younger than the schist belt. The cataclastic granite is red and medium-grained, with an oriented structure due to its very strong cataclase. The cataclase originated when the schist belt and the basement moved in relation to each other.

\section{Dikes}

There are four metadiabase and two aplite dikes in the schist belt of Tipasjärvi. Both dike types brecciate the schists.

The metadiabas es are aphanitic finegrained and massive. Blastophitic structure is preserved only in one metadiabase dike. Quantitatively hornblende is the dominative mineral. Other chief minerals are plagioclase and quartz.

The a plites are massive, medium- and even-grained dikes. Albitic $\left(A n_{7}\right)$ plagioclase is the dominative mineral, although there is also a large amount of quartz. An unidentified brownish mass occurs between the above minerals.

\section{Tectonics of the schist belt}

All the rocks of the schist belt are schistose except the talc-chlorite-carbonate-rock and the dikes. The schistosity is parallel to the contours of the rocks. Thus, the common strike of the schistosity is NW-SE (Fig. 2). The dip is variable, but its general direction is to the SW. The folding type is isoclinal.

The lineation largely coincides with the axes of minor folds, whose strikes are usually to the south and plunges are $50^{\circ}-70^{\circ}$. These and the deformation structures between the schist belt and the basement (the basal schist) show that the schist belt has, in part at least, been pressed under the basement. Thus the culmination is situated north of the schist belt.

The Vuorisaari-Vuoriniemi-Kangaslampi area (Fig. 2) represents the most deformed section of the schist area. The strong deformation is indicated by the tectonic breccia of the micaquartz-schist, the fragmental structure of the amygdalar amphibolite and the talc-chloritecarbonate-rock as well as by the mylonisation of the fine-grained amphibolite and the faults of various sizes. Otherwise, the schist belt has no peculiar tectonic structures. 
The tectonics of the schist area of Tipasjärvi corresponds to the tectonic pattern of Lover Proterozoic formations as presented by Russian geologists. According to Kratz (1960), the early Karelian folding gathered Lower Proterozoic formations to a great extent into steep, tightly stressed, isoclinal folds which in most cases are inclined to diapires, domes or local culminations. Thus the schist belt of Tipasjärvi is inclined to its nothern culmination. The early Karelian folding according to the interpretation of the Russians obviously gave the schist belt of Tipasjärvi so firm a structure that later orogenies have not been able to affect.

\section{The geological development of the Tipasjärvi district and the position of the schist area in the evolution of the bedrock in eastern Finland}

The structures of the arenites show that they were consolidated from the material transported for a short distance from the granite gneiss. Based on the general stratigraphic principles one can state that the arenites and the argillites were deposited in the same basin. But one cannot say if the argillaceous material was deposited straight on the arenites or if there was an unconformity between them, for the basic magmatism has destroyed the connection of these sedimentary formations.

The coarse-grained amphibolite which has been thoroughly metamorphosed and lost all its primary structural features, obviously represents a deeper and previously crystallised basic rock. Later a partly extrusive magmatism followed. The products of this have been converted into the fine-grained amphibolites. The talcchlorite-carbonate-rock and the hornblendechlorite-schist have originated from ultrabasic rocks.

As a whole the high grade of the metamorphism of the schist belt (amphibolite fasies), the vanishing of the primary structural features and the steep, isoclinal folds have demanded intensive folding.
The late kinematic granites, the metadiabases and the aplites are the youngest rocks in the $\mathrm{Ti}$ pasjärvi district. They intruded after folding.

The schist area of Tipasjärvi is regionally a small unit (Fig. 1) which, nevertheless, does not prevent discussion of its position in the evolution of the bedrock in eastern Finland. The matter has previously been under consideration in literature: according to Wilkman (1921) the Tipasjärvi belt belongs to the Kalevian formations; on the map of Mikkola (1961) it is a Jatulian or Kalevian formation; Väyrynen (1954) regards it, as well as the schist belt of Kuhmo-Suomussalmi and Ilomantsi, as pre-Karelian, which the discordance separates from the Karelian formations, but whose basement is unknown; according to Matisto (1958) the Kuhmo-Suomussalmi belt, to which the schist area of Tipasjärvi indirectly belongs, is a Karelian formation with basal conglomerates, and finally Eskola (1963) places the schist belt of Tipasjärvi on a level with the Otravaara and Hevoskumpu (Tuupovaara) areas, which are pre-Karelian and enclosed by granite gneiss.

The fact is that the granite gneiss does not penetrate the schist belt of Tipasjärvi. The deformation has destroyed the actual contact of the schist area with the granite gneiss (the basal schist). The observations from the arenites however indicate that they deposited on the granite gneiss. But the rocks of the Tipasjärvi belt, as those of Kuhmo-Suomussalmi belt, are of different type from the Jatulian and Kalevian rocks. Also their litological association is different. In Tipasjärvi, the typical Sariolan facies does not occur, the marine-Jatulian is absent, the arenites of Tipasjärvi and the quartzites as well as the quartz-feldspar-schist of the Kuhmo-Suomussalmi belt have no resemblance with the Kainuuan quartzites and the Karelian serizite-quartzites.

The strong recrystallisation and the vanishing of the structural features, the strong schistosity of the rocks and the stressed pattern of folding do not characterise the Karelian formations. 
On the basis of the evidence given above one hardly can consider the Tipasjärvi sequence:

- mica-schist

- amphibolites and ultrabasic rocks

- arenites,

as a part of the basement or as a Jatulian or Kalevian formation. It seems possible that the schist belt of Tipasjärvi have deposited on the granite gneiss but is older than the Karelian formations.

The Russians have continuously explored the Kola and Karelia. These are the key districts in questions concerning the Precambrian stratigraphy (Timofejev, 1934, Robonen, 1958, Kratz, 1958, Haritonov, 1962, Bogdanov et al., 1962, Simon, 1965, Semihatov, 1966). The students of these districts are not quite unanimous about the stratigraphy of the Precambrium (Negrutsa, 1967). The opinions of the Finns and the Russians also differ from each other in respect of the stratigraphy of the eastern part of the Baltic Shield. These differences can be briefly set forth as follows:

Finns

Jotnian

\begin{tabular}{lll} 
Kalevian & \\
Jatulian & Sariolan & Middle Proterozoicum \\
\hline - & &
\end{tabular}

BASEMENT, the granite gneiss complex

Pre-Karelian schists

The most noteable difference between the Finnish and Russian terminology is that the Russians have a section of the Karelian formations which is still older than the Sariolan and which they call Lower Proterozoicum.
This Lower Proterozoicum is divided according to Kratz (1969) into lower and upper section. The lower section grades gradually into the Archean or lies discordantly on it. To the lower section belong basic volcanites, leptites, different phyllites, mica-, talc-, chlorite-, etc. schists, magnetite-quartzites and different amphibolites. To the upper section belong basic extrusive rocks, quartzites, arkoses and mica-, etc. schists. The rocks of Tipasjärvi resemble in the first place the rocks of the lower section. Thus, the biotiteand quartz-sericite-schists, the different amphibolites and the metamorphic ultrabasic rocks of the Pohmos-Prosozero series (Kratz, 1958), the quartzite-schists and phyllites of the Himola-Kosozero lake series (Robonen, 1958), the slates and the volcanic amphibolites of the Himola-Parantova series (Simonen, 1957) are fairly similar to the corresponding rocks of Tipasjärvi. It was mentioned above that basic volcanites and iron ores are typical of the lower section of the Lower Proterozoicum. These do not occur in Tipasjärvi but Papunen (1960) has descriped them from the Siivikkovaara area in the Kuhmo-Suomussalmi schist belt. The geological development and the tectonic structure of the Tipasjärvi schist belt presented above, are also analogical to those of the Lower Proterozoicum. According to Kratz (1960), the intensive geosynclinal sedimentation of the Lower Proterozoicum began with the deposition of the sedimentary and volcanic beds whilst spilitekeratophyres and quartz-banded iron ores originated. Terrigenic flysch material ended the sedimentation. During the pre-Karelian folding ultrabasic, basic and intermediate magmas intruded and after the folding the intrusions of microclinegranites, which are partly microcline-orthoclasegranites, took place.

The similarity in geological development, tectonic structure and lithological nature between the schist belt of Tipasjärvi and the Lower Proterozoic formations of the Russians seems to indicate that the schist belt of Tipasjärvi could be placed on a level with the 
Lower Proterozoicum, above all with its lower section.

The schist belt of Tipasjärvi is probably a depression preserved as a relict from a longer zone, which was in line with the Kuhmo-Suomussalmi belt (Fig. 1). According to Kratz (1960), the Lower Proterozoic fold structures directed the outlines of the Middle Proterozoic (Sariolan, Jatulian, Kalevian) geosynclines. This is also the case in the Kainuu district. The schist areas of Tipasjärvi and Kuhmo-Suomussalmi are parallel the basins of the Kainuu and Kuusamo belts (Fig. 1).

On the basis of all that has been descriped above, it seems probable that formations might occur in eastern Finland which are deposited on the granite gneiss complex but which are older than the Sariolan, Jatulian and Kalevian formations. These older formations may be placed on the level of the Lower Proterozoicum. The schist area of Tipasjärvi and Kuhmo-Suomussalmi may be of this age as also the schist belt of Ilo- mantsi (Fig. 1), the rocks of which are quite similar to those of Tipasjärvi (Väyrynen, 1954). According to Väyrynen (1954) and Eskola (1963) the schists of Ilomantsi are pre-Karelian. Thus, one may present the stratigraphic scale of the schist areas in eastern Finland as follows:

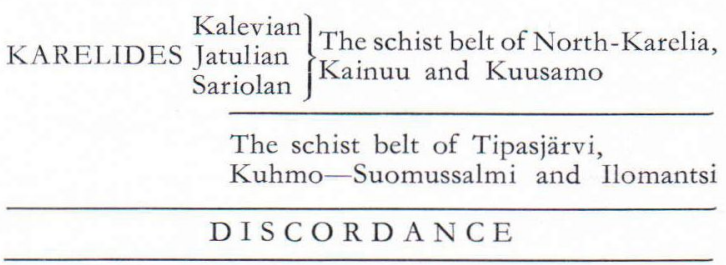
THE GRANITE GNEISS COMPLEX

The schist areas of Tipasjärvi, Kuhmo-Suomussalmi and Ilomantsi principally include the phases of the orogenic cycle: the sedimentation on the granite gneiss, the folding and the magmatism connected with it and finally the intrusions of the late kinematic granites. These features may indicate that the schist belts in question could represent an independent orogeny.

\section{REFERENCES}

Bogdanov, J., Voinov, A., Suhanov, V., \& HarotoNov, L. (1962) Karelisen muodostuksen rakenteellisesta suhteesta Kemin alueella Itä-Karjalassa,

Doklady Akademii Nauk SSSR, 3. The translation collection of Geological Survey of Finland, 21.

Eskola, P. (1963) The Precambrian of Finland. - The Geologic Systems: The Precambrian, edited by $\mathrm{K}$. Rankama, London.

Haritonov, L. J. (1962) Balttilaisen kilven geologisen rakenteen pääpiirteet. - Moskova-Leningrad. The translation collection of Geological Survey of Finland, 10.

Kratz, K. O. (1958) Karjalan proterozoicumin jaottelusta ja terminologiasta. - Izvestija Kareljskogo i Koljskogo filialov Akademii Nauk SSSR, 3. The translation collection of Geological Surveys of Finland, 5.

- (1960) Balttilaisen kilven itäosan prekvartäärisen geologian pääpiirteet. — Trudy Laboratorii Geologii Dokembrija, 9. The translation collection of Geological Surveys of Finland.
Matisto, A. (1958) Suomen geologinen yleiskartta, Leht: D 5. Suomussalmi. Kivilajikartan selitys.

Mrkkola, T. (1961) Sediment groups, particularly flysch, of the Precambrian in Finland. - Bull. Comm. géol. Finlande, 196.

Negrutsa, T. F. (1967) Karelidien geologinen rakenne Lehtinskin synkliinin lounaissiivellä. - Vestnik leningradskova Universiteta, 18. Finnish translation as manuscript by V. Makkonen, Rautaruukki Co.

Papunen, H. (1960) Havaintoja Siivikkovaaran alueen kallioperästä Kuhmon pitäjän Vieksin kylässä. Manuscript at the Institute of Geology, University of Helsinki.

Robonen, V. I. (1958) Karjalassa olevan ent. Tunkueen (Tungude) piirin ala-proterozoicumin stratigrafiaa koskevia uusia tietoja. - Trudy Kareljskogo filiala Akademii Nauk SSSR, 11. The translation collection of Geological Survey of Finland, 3.

Semifatov, M. A. (1966) Prekambriumin stratigraafisen kaavion probleemasta. - Izv. An. SSSR, 4. Finnish traslation as manuscript by V. Makkonen, Rautaruukki Co. 
Simon, A. (1957) Kuollan karelidien stratigrafiasta. Doklady Akademii Nauk SSSR, 165. The translation collection of Geological Survey of Finland, 42.

Simonen, A. (1957) Itä-Karjalan ja Kuolan kallioperästä. Geologi, 10.

- (1960) Pre-Quaternary rocks in Finland. - Bull. Comm. géol. Finlande, 191.

Trmofejev, W. W. (1934) Die Geologie Kareliens. »Arbeiten der Ersten Allsowjetischen Forschungskonferenz für wissenschaftliche gcologische Prospektion». Leningrad. The translation collection of Geological Survey of Finland, 33.
VArtiainen, H. (1965) Tipasjärven alueen kallioperä. Manuscript at the Institute of Geology, University of Oulu.

- (1966) Tipasjärven breksia/konglomeraatti Sotkamon pitäjän kaakkoisosassa. - Geologi, 3-4.

WILKMAN, W. W. (1921) Suomen geologinen yleiskartta, Lehti D 4. Nurmes. Vuorilajikartan selitys. Geologinen komissio.

VäYrynen, H. (1954) Suomen kallioperä. Helsinki.

Manuscript received, April 15, 1969 